\title{
Utilization Of Watershed Tukad Badung As Denpasar City Water Tourism (Environmental Law Perspective)
}

\author{
I Ketut Kasta Arya Wijaya, I Wayan Arthanaya, Luh Putu Suryani \\ \{kastaaryawijaya@gmail.com\} \\ Law Faculty of Universitas Warmadewa, Denpasar, Bali, Indonesia
}

\begin{abstract}
The purpose of this study is to examine the legal aspects of regional government authority in managing watersheds in Tukad Badung. This is an effort to create a clean environment to benefit the entire community. In Law Number 23 of 2014 on Regional Governments, there is an authority mentioned in Article 11 concerning concurrent government affairs. Obligatory Government Affairs as referred to in paragraph (1) relates to basic and non-basic Services. Article 12 of Law Number 23 Year 2014 on Regional Government states the Obligatory Government Regulations relating to Basic Services as referred to in Article 11 paragraph (2), including a) education, b) health, c) public works and spatial planning. In relation to basic services, the obligations of the Regional Government include public works and spatial planning, which involves organizing and utilizing one of the watersheds in Tukad Badung. A healthy, clean and safe environment is part of human rights stipulated in the constitution. Article 28 (I) states that every person has the right to obtain a healthy and clean environment. Therefore, the arrangement of the Tukad Badung watershed for water tourism plays a significant role in maintaining cleanliness and preventing pollution.
\end{abstract}

Keywords: Watershed, Water Tourism, Environment

\section{Introduction}

In the middle of the city of Denpasar across a river known as the Tukad Badung river basin. Tukad Badung is one of the rivers that flows and enters Denpasar City after it flows from the Badung Regency area. The existence of the river is very beneficial for the fulfillment of the needs of human life and as an aquatic environment for living creatures around it, besides that as a drainage of rainwater into the sea [1]. Denpasar city government through the Public Works Department (PU) of Denpasar City has arranged the Badung River (Tukad) river management starting from under the Jalan Gajah Mada Bridge. The arrangement of paving and stone brushes on the side of a riverbank to eliminate the dirty and dirty river views becomes something interesting and clean. In addition, it is also an education for residents near the river to help maintain environmental cleanliness and no longer throw garbage into the river. This arrangement is in addition to recreation such as fishing grounds, as well as education for residents, especially those who are close to the riverbanks to help maintain cleanliness by no longer throwing garbage into the river. Furthermore, in this study will look 
at aspects of authority from the Denpasar city government in managing the Tukad Badung Watersheds related to the laws and regulations that apply in spatial planning, later this research will focus on local government authority and whether there is synchronization with laws and regulations. Underneath it and is there any benefit in the arrangement of the Tukad Badung Watersheds. According to [2] in their research stated that the government policy in structuring the river was very good, this can be seen from the implementation of government policy by structuring in several areas of the Badung river. However, the arrangement of the Badung River has not been maximized which should have been oriented to the changes in the lifestyle of the people living around the river.

Furthermore, a research done by [3] at watershed Jeneberang, South Sulawesi. His finding stated that watershed is believed to be a complex and evolving ecosystem with changes in time, therefore, by knowing the legal aspects in the management of the Jeneberang watershed, ecosystem damage that occurs as a result of activities carried out in watersheds can be minimized or in other words avoided. In line with the preceding research above, according to [4] in integrated watershed management it must be based on: (1) utilization of natural resources (forest, land and water) with due regard to environmental protection; (2) watershed management is multidisciplinary and cross-sectional; (3) improvement of people's welfare; (4) integration starts in the planning of integrated watershed management.

That is why in conducting this study is in accordance with the vision and mission of Warmadewa University College which is oriented towards environmental aspects, where the development carried out must be based on development that pays attention to the environment, is sustainable and can provide benefits to the community at large later this research will contribute in the legal aspects of spatial planning in the special watershed in Tukad Badung in Denpasar.The Tukad Badung is area as the focus of this research is included in the conservation and revitalization area besides that around the Tukad Badung area has the potential to be able to function in order to increase and develop community empowerment in the area around the area. From the background described above, the problem can be formulated as follows: 1) what is the legal basis for the authority of the Denpasar City Government in structuring the utilization of the Tukad Badung Watersheds as a water tourism facility and 2) how are aspects of environmental law related to the arrangement of the utilization of the Tukad Badung Watersheds as a water tourism facility in Denpasar?

\section{Method}

This study uses normative legal research then in strengthening its legal material supported by field data through observation and conducting interviews with the community that is around the research location, namely in Tukad Badung. The legal materials used are primary legal materials and secondary legal materials. Ranging from laws and regulations to the level of regional regulation. It is further supported by the results of previous studies relating to watersheds. The data and legal materials that are in the analysis and are described in accordance with the existing legal materials that have been analyzed. The approach used is a conceptual approach, legislation and comparison approach.

\section{Results And Discussion}

\subsection{Authority of Local Governments in Utilizing Watersheds as Water Tourism}


The principle of legality is one of the main principles that forms the basis of the administration of government and state based on law. The idea of the rule of law demands that the administration of government guarantee the basic rights of the people. The principle of legality in question is the authority granted by law. The authority has an important position in the study of law in the field of government or administrative law. Once the importance of authority in administrative law in the administration of government because it relates to the rights and obligations that must be carried out. P. Nicolai states "the ability to take certain legal actions (is actions intended to cause legal consequences, and include the arising and disappearing of legal consequences). The right contains the freedom to do or not do certain actions, while the obligation includes to do or not do certain actions [5]

The replacement of the Local Government Law in 2014 provides direction on the pattern of division of government functions between the center and the regions, namely Law Number 23 of 2014. Now, based on the provisions of Article 9 of the Regional Government Law, the classification of Government affairs consists of absolute government affairs, concurrent government affairs, and affairs general government. Absolute government affairs are government matters that are fully the authority of the Central Government. Concurrent government affairs are Government Affairs that are shared between the Central Government and provincial and district/city governments. Concurrent government affairs submitted to the Regions form the basis for the implementation of Regional Autonomy. Meanwhile, general government affairs are Government Affairs which become the authority of the President as the head of government. The division of concurrent government affairs between the Central Government and the provincial and district/city regions as mentioned above is based on the principle of accountability, efficiency, and externality, as well as national strategic interests [5].Based on the provisions of the Regional Government Law, it is clearly seen that the basis for the implementation of regional autonomy is the concurrent government affairs that are submitted to the regions [5]. Therefore, the regulation of the implementation of basic government services compulsory mandatory is a necessity, because the basic government affairs compulsory service is part of the concurrent government affairs that form the basis of Regional Autonomy. In other words, it can be said that without the implementation of concurrent government affairs, there is no regional autonomy. The implementation of governmental authority in the regions both by province and district/city in the spatial planning sector including in the watershed area arrangement which is the basis of authority is Law No. 23 of 2014 concerning Regional Government, namely in concurrent government affairs.

In Law Number 32 of 2009 concerning PPLH (environmental protection and management) it is explained about the principle of Ecoregion ". The principle of ecoregion is that environmental protection and management must pay attention to the characteristics of natural resources, ecosystems, geographical conditions, local community culture, and wisdom local. Bioregion is a geographical-biotic region that is part of the surface of the earth or nature or ecosystems whose boundaries are not determined by human will but by the nature of nature itself that is unique and distinctive, which is at once distinguished and distinguished from other regions due to its characteristics and the distribution of its fauna and flora, its water, its land cover, its landscape, and human settlements and their culture as a result of local human interaction with the local nature.

This bioregion is associated with a watershed, Watershed, which describes the unity of the area of natural ecosystems and human communities as a unity of lifestyle in harmony with nature, which unites the local ecosystem, economy and culture as one natural, human unity. Thus looking at the principles or guidelines in the watershed existing in Tukad Badung must pay attention to the existing approach in the principle of bioregionalism or ecoregion. So that 
in the future the use of watersheds in Bali as water tourism needs to be made in the form of legal instruments in the form of district/city regulations, so that it provides more legal aspects in normalization related to the bioregoinalism or ecoregion approach. This is because the authority relating to environmental or spatial planning is in the district/city so that the regency government can provide more basic services to the community in accordance with what is the objective of the implementation of regional autonomy.

\subsection{The Role of Environmental Law in the Arrangement of Watershed in Tukad Badung.}

Law of the Republic of Indonesia Number 32 of 2009 concerning Environmental Protection and Management states that the Environment is a unitary space with all objects, power, conditions and living things including humans and their behavior that affect nature itself, the continuity of life and human well-being another life. Environmental Protection and Management is a systematic and integrated effort carried out to preserve environmental functions and prevent environmental pollution and / or damage which includes planning, utilization, control, maintenance, supervision and law enforcement of environmental development. Denpasar as a tourist destination city in its activities provides a direct influence on environmental sustainability. As the capital city of the province with the right location in the middle of the island of Bali, Denpasar City is a tourism gateway that will not be missed by tourists visiting Bali. This makes the tourism sector in Denpasar develop very rapidly and become a leading sector for the economy of Denpasar as a whole. Based on data from the City of Denpasar Tourism Office, the number of tourist visits to the city of Denpasar has increased 5 years back from 2012-2016. To support tourism, Denpasar City in 2017 Denpasar City has 33 five-star hotels, and 253 non-star hotels. Even based on Denpasar in Figures for 2017 stated that the average length of stay of foreign tourists was 4.28 days in 2016 while domestic tourists were 1.9 days in the same year. This shows the potential for the development of tourism in the city of Denpasar very well.

Based on what has been described above, it can be concluded that the role of environmental law in the arrangement of the Tukad Badung Watershed is very significant, this is due to environmental aspects which are the main objective in the arrangement. A healthy, clean and safe environment is part of human rights, which is stipulated in the constitution, Article 28 (I) that every person has the right to obtain a healthy and clean environment is part of human rights. Thus the arrangement of the Tukad Badung watershed for water tourism for the people of Denpasar in particular and the general public outside the city of Denpasar, also plays a role in maintaining cleanliness, and preventing pollution in watersheds.

\section{Conclusion}

The authority of regional governments in the utilization of watersheds can be seen in Law Number 23 of 2014 concerning Regional Government, which is related to the affairs of the administration of concurrent government, concurrent government affairs as intended in Article 9 paragraph (3) which becomes the authority Regions consist of Obligatory Government Affairs and Preferred Government Affairs, functions that are obligatory as basic services related to spatial planning, and which are not basic services namely the environment, and optional affairs relating to tourism. Thus the use of watersheds as water tourism covers the whole of government affairs in the city area both in terms of basic services related to spatial planning, then what is not a basic service is related to the environment and choice of 
government affairs related to tourism in this case as tourism water. The role of environmental law in the management of watersheds that the role of environmental law in the management of the Tukad Badung Watershed is very significant, this is due to environmental aspects which are the main objective in the arrangement. A healthy, clean and safe environment is part of human rights, which is stipulated in the constitution, Article 28 (I) that every person has the right to obtain a healthy and clean environment is part of human rights. Thus the arrangement of the Tukad Badung watershed for water tourism for the people of Denpasar in particular and the general public outside the city of Denpasar, also plays a role in maintaining cleanliness, and preventing pollution in watersheds.

\section{References}

[1] M. S. Mahendra, I. W. B. Suyasa, I. W. Nuarsa, A. R. Asy-syakur, and N. M. Ernawari, "Kajian Kualitas Perairan Tukad Badung di Kota Denpasar Bali,” p. 25, 2015.

[2] I. G. K. Purnaya and I. M. T. Semara, "Implementasi Kebijakan Pemerintah Terhadap Penataan Sungai Badung Dalam Upaya Pengembangan Pariwisata Di Kota Denpasar," J. Ilm. Hosp. Manag., vol. 8, no. 2, pp. 1-10, 2018.

[3] R. Bohari, Aspek Hukum Dalam Pengelolaan DAS (Studi Kasus Das Jeneberang Sulawesi Selatan). Tesis. Jakarta: Perpustakaan Universitas Indonesia (UI).

[4] Sudaryono, "Pengelolaan Daerah Aliran Sungai (DAS) Terpadu, Konsep Pembangunan Berkelanjutan,” J. Teknol. Lingkung., vol. 3, no. 2, pp. 153-158, 2002.

[5] J. Ridwan and A. Sodik, Hukum Administrasi Negara dan Layanan Publik. Bandung: Nuansa Cinderia, 2014.

[6] Novianto M. Hantoro, Sinkronisasi Dan Harmonisasi Pengaturan Mengenai Peraturan Daerah Serta Uji Materi Peraturan Daerah Provinsi Bali Nomor 16 Tahun 2009 Tentang Rencana Tata Ruang Wilayah Provinsi Bali Tahun 2009-2029

[7] Laporan Penelitian Kajian Kualitas Perairan Tukad Badung Di Kota Denpasar, Bali Program Studi Magister Ilmu Lingkungan Program Pascasarjana Universitas Udayana Denpasar 2015.

[8] Undang-Undang Nomor 5 Tahun 1960 tentang Peraturan Dasar Pokok-Pokok Agraria (Lembaran Negara 1960 - 104, Tambahan Lembaran Negara Nomor 2043)

[9] Undang-Undang Nomor 11 Tahun 1974 tentang Pengairan (Lembaran Negara Republik Indonesia Tahun 1974 Nomor 65, Tambahan Lembaran Negara Republik Indonesia Nomor 3046)

[10] Undang-Undang Nomor 32 Tahun 2009 tentang Perlindungan dan Pengelolaan Lingkungan Hidup.

[11] Undang-Undang Nomor 12 Tahun 2011 tentang Pembentukan Peraturan perundang-undangan.

[12] Undang-Undang Nomor 26 Tahun 2007 tentang Penataan Ruang.

[13] Perda Provinsi Nomor 16 tahun 2009 tentang RTRW Provinsi bali

[14] Perda Kota Denpasar Nomor 27 tahun 2011 tentang RTRW Kota Denpasar 